\title{
COMPARISON OF TECHNIQUES- IDENTIFICATION OF EPIDURAL SPACE USING THE LOSS OF RESISTANCE SYRINGE AND AN AUTOMATED SYRINGE
}

\author{
G. Dilish ${ }^{1}$, K. Murugesan², R. Jayasree ${ }^{3}$
}

${ }^{1}$ Assistant Professor, Department of Anaesthesiology, Government Mohan Kumaramangalam Medical College, Salem. ${ }^{2}$ Associate Professor, Department of Anaesthesiology, Government Mohan Kumaramangalam Medical College, Salem. 3Junior Resident, Department of Anaesthesiology, Government Mohan Kumaramangalam Medical College, Salem.

\section{ABSTRACT}

\section{BACKGROUND}

With the concerns regarding the higher amount of time taken for epidural needle insertion and higher failure rate and complication rate with conventional loss of resistance techniques, various new innovative techniques have been introduced into anaesthetic practice. But the studies comparing these advanced methods on Indian population with conventional methods are scarce.

The aim of this study is to compare the efficacy of identification of epidural space using conventional LOR syringe versus automated Epimatic syringe.

\section{MATERIALS AND METHODS}

The study included 40 patients undergoing lumbar epidural anaesthesia with 20 patients in each of the Automatic Epimatic syringe group and conventional LOR group. All the patients were aged between 18 to 65 years, belonging to both genders and with ASA status - I, II, III.

Settings and Design- The study was a randomised controlled trial conducted in Government Mohan Kumaramangalam Medical College Hospital, which is a tertiary care teaching hospital in South India.

Statistical Analysis- Since all the quantitative variables were not normally distributed, they were compared between two groups using median and interquartile range using Mann-Whitney U test. The categorical variables were compared between two groups by Chi square test or Fisher's exact test. IBM SPSS version 21 was used for statistical analysis.

\section{RESULTS}

Both groups were comparable regarding age, sex, weight, the frequency of distribution. Number of attempts taken is statistically insignificant with $\mathrm{p}$ value 0.32 , the time taken to identify the epidural space is statistically significant with $\mathrm{p}$ value $<0.001$, In ease of identification of epidural space, $p$ value is 0.30 , In ease of catheter insertion $p$ value is 0.34 , both are statistically not significant and we encountered one dural tap in conventional LOR syringe group,

\section{CONCLUSION}

Epimatic syringe being a newer hands-free technique taking less time to identify the space with less complications is an ideal technique for beginners. It is a safe alternative for conventional loss of resistance technique.

\section{KEYWORDS}

Epidural Anaesthesia, Needle Insertion, Epimatic Syringe, Loss of Resistance.

HOW TO CITE THIS ARTICLE: Dilish G, Murugesan K, Jayasree R. Comparison of techniques- The identification of epidural space using the loss of resistance syringe and an automated syringe. J. Evolution Med. Dent. Sci. 2017;6(80):5657-5660, DOI: $10.14260 /$ jemds/2017/1226

\section{BACKGROUND \\ Epidural anaesthesia is one of the most commonly used modality of anaesthesia in modern anaesthetic practice. Since its introduction, it has gained wider acceptance for surgical anaesthesia, intraoperative, post-operative analgesia and labour analgesia.(1) Epidural anaesthesia is a blind procedure, it is difficult to accurately identify the epidural space resulting into $1.5 \%$ failure rate because of excess fat, undue ossification or repeated puncture of the dura mater.(2) To localise epidural space, various techniques have been used. These techniques either take}

'Financial or Other Competing Interest': None.

Submission 01-09-2017, Peer Review 24-09-2017,

Acceptance 30-09-2017, Published 05-10-2017.

Corresponding Author:

Dr. G. Dilish,

\#121/8K, Raghuram Colony,

Gandhi Road, Salem-636007, Tamilnadu.

E-mail:drdilish@yahoo.co.in

DOI: $10.14260 /$ jemds $/ 2017 / 1226$ advantage of potential negative pressure in the epidural space or use the sudden disappearance of resistance when ligamentum flavum is penetrated.(3,4)

Various techniques or modifications of the existing techniques have been evolved since its inception to accurately identify the epidural space. These methods included negative pressure methods like hanging drop method, capillary tube and manometer indicator methods, $(5)$ disappearance of resistance techniques like syringe technique, Brook's method, modified pressure technique,(6) the balloon technique, spring loaded syringe, etc. $(7,8)$

But the relative superiority of these techniques as reported in many studies is still inconclusive as many study findings are contradictory to each other. Each of the techniques have been reported to have their own advantages and disadvantages. Study findings are also varied with the sociodemographic and physical characteristics of the study population included. Hence, it is better to evaluate the relative superiority of different techniques in native population to guide clinical practice. But the amount of 
literature on the subject is scarce from India. Hence, the current study has been conducted with an objective to compare the efficacy of epidural space identification and the complication rate of conventional loss of resistance syringe versus automated Epimatic syringe techniques.

\section{MATERIALS AND METHODS}

The current study was conducted in the Department of Anaesthesia, Government Mohan Kumaramangalam Medical College Hospital, Salem, Tamilnadu which is a tertiary care teaching hospital. The study population included adults aged above 18 years, undergoing lower torso procedures in both elective and emergency surgeries in the study setting from June 2017 to August 2017, over a period of 3 months.

\section{The Study was a Randomised Controlled Trial of two} different Intervention Groups-

Group C- In which conventional loss of resistance syringe method was used.

Group E- In which automated Epimatic syringe method was used.

The study sample included 20 subjects in each of the intervention groups. The sample size was calculated assuming the difference of accurate identification of epidural space, in group C it was $52.4 \%$ and in the group E it was $87.5 \%$ as per a study by Duniec $\mathrm{L}$ et al.(3) The other parameters used for sample size calculation were $80 \%$ power of the study and 5\% alpha error. The required sample size was about 20 subjects in each of the intervention groups as calculated using STATA IC software version 13.

Randomisation was done using computer generated random number sequence and the allocation sequence was kept in serially numbered opaque envelopes in the custody of an independent statistician. The intervention sequence was revealed after recruiting the subject and obtaining the informed written consent. The investigator blinding was not possible considering the nature of the intervention. Participant blinding was not required as the outcome assessment was based on investigator perception of loss of resistance or ultrasound guided.

The inclusion criteria of the study were age between 18 to 65 years, weight of the subject between 40 to $75 \mathrm{~kg}$, ASA status- I, II, III and patients undergoing Lower torso procedures.

After informed written consent, established Standard monitoring like ECG, non-invasive blood pressure, saturation etc. were done. IV access was established. Epidurals were performed in sitting position and under strict aseptic precaution. Local infiltration done using $3 \mathrm{cc}$ of $2 \%$ lignocaine in desired space and 17G Tuohy needle \& 19G catheter used. Later Tuohy needle was inserted until mild resistance approximately at the level of interspinous ligament and the stylet was removed, the automated syringe or LOR syringe was attached, then the needle was advanced slowly until loss of resistance is achieved.

Primary objectives like the number of attempts taken to identify the epidural space that is number of skin pricks were noted, the time taken to identify the epidural space is the time interval between attaching the syringe after removal of the stylet and successful identification of space which was recorded using a stop watch. Ease of space identification that is the visible movement of the plunger during advancement of the needle, was graded using a 3-point scale: 1 - a distinct decrease, 2 - barely detectable, 3 - no decrease in plunger was noted using both conventional losses of resistance syringe and automated Epimatic syringe. After space is identified the epidural catheter was inserted and the ease of catheter insertion was graded using a 3-point scale: 1 - No resistance while inserting, 2 - mild resistance encountered, 3 - not able to insert the catheter, then complications like dural punctures were recorded.

All the quantitative values were assessed for compliance with normal distribution. Both the study groups were compared with respect to normally distributed quantitative variables using mean and standard deviation using unpaired t-test. Non-normally distributed quantitative variables were compared using median and interquartile range and MannWhitney $\mathrm{U}$ test was used to test statistical significance. Categorical variables were compared by cross tabulation. Chisquare test was used when the minimum number of people in any cell was more than 5, or else Fisher's exact test was used. No statistical test could be used for comparative tables with " 0 " number of subjects in any of the cells. P Value $<0.05$ was considered as statistically significant. IBM SPSS version 21 was used for statistical analysis.

\section{RESULTS}

A total of 40 patients were included in the analysis.

\begin{tabular}{|c|c|c|c|}
\hline Parameter & $\begin{array}{c}\text { Automated } \\
\text { Epimatic } \\
\text { Syringe } \\
(\mathrm{N}=20)\end{array}$ & $\begin{array}{l}\text { Conventional LOR } \\
\text { Syringe }(\mathrm{N}=20) \\
\text { Median } \\
\text { (Interquartile } \\
\text { Range) }\end{array}$ & $\begin{array}{c}(\mathbf{P} \\
\text { Value })\end{array}$ \\
\hline $\begin{array}{c}\text { Age } \\
\text { Median } \\
\text { (Interquartile } \\
\text { Range) }\end{array}$ & $43(27,54)$ & $47(33,60)$ & 0.289 \\
\hline $\begin{array}{c}\text { Weight } \\
\text { Median } \\
\text { (Interquartile } \\
\text { Range) }\end{array}$ & $57(54,62)$ & $61(48,68)$ & 0.718 \\
\hline $\begin{array}{l}\text { Male: Female } \\
\text { (Ratio) }\end{array}$ & $1: 1$ & $1: 1$ & - \\
\hline $\begin{array}{r}\text { Tab } \\
\text { with } S t u\end{array}$ & $\begin{array}{l}\text { Associatic } \\
\text { roup of } S\end{array}$ & $\begin{array}{l}\text { f Age and Weight } \\
\text { y Population }(N=\end{array}$ & \\
\hline
\end{tabular}

There were no statistically significant differences in age, weight and gender composition between the study groups. (Table 1).

\begin{tabular}{|c|c|c|}
\hline \multirow[b]{2}{*}{$\begin{array}{c}\text { No. of } \\
\text { Attempts }\end{array}$} & \multicolumn{2}{|c|}{ Group } \\
\hline & $\begin{array}{c}\text { Automated Epimatic } \\
\text { Syringe }\end{array}$ & $\begin{array}{c}\text { Conventional LOR } \\
\text { Syringe }\end{array}$ \\
\hline 1.0 & $16(80 \%)$ & $11(55 \%)$ \\
\hline 2.0 & $3(15 \%)$ & $7(35 \%)$ \\
\hline 3.0 & $1(5 \%)$ & $1(5 \%)$ \\
\hline 4.0 & $0(0 \%)$ & $1(5 \%)$ \\
\hline $\begin{array}{r}\text { Tab } \\
\text { with }\end{array}$ & $\begin{array}{l}\text { Association of } \mathrm{Nu} \\
\text { dy Group of Study } F\end{array}$ & $\begin{array}{l}\text { of Attempts } \\
\text { Ilation }(N=40)\end{array}$ \\
\hline
\end{tabular}

The proportion of subjects in which the needle was inserted in first attempt was $80 \%$ with Automated Epimatic syringe and $55 \%$ in in conventional LOR syringe. The 
proportion of subjects in which 2 and 3 attempts were taken to insert syringe were $15 \%$ and $5 \%$ in Automated Epimatic syringe group, but none required 4 attempts. In conventional LOR syringe group, the proportion of subjects requiring 2, 3 and 4 attempts were $35 \%, 5 \%$ and $5 \%$ respectively. No statistical test of significance could be applied to this table due to "0" subjects in one of the cells. (Table 2).

\begin{tabular}{|c|c|c|c|}
\hline \multirow[b]{2}{*}{ Parameter } & \multicolumn{2}{|c|}{ Group } & \multirow[b]{2}{*}{$\begin{array}{c}\text { Mann- } \\
\text { Whitney } \\
\text { U Test P } \\
\text { Value }\end{array}$} \\
\hline & $\begin{array}{l}\text { Automated } \\
\text { Epimatic } \\
\text { Syringe } \\
\text { Median } \\
\text { (IQR) }\end{array}$ & $\begin{array}{c}\text { Conventional } \\
\text { LOR } \\
\text { Syringe } \\
\text { Median (IQR) }\end{array}$ & \\
\hline $\begin{array}{l}\text { Time taken } \\
\text { to Identify } \\
\text { the space (in } \\
\text { sec.) }\end{array}$ & $8(6,11)$ & $35(28,45)$ & $<0.001$ \\
\hline \multicolumn{4}{|c|}{$\begin{array}{c}\text { Table 3. Association of Time Taken to Identify the } \\
\text { Space (in sec.) with Group of Study Population }(N=40)\end{array}$} \\
\hline
\end{tabular}

The median amount of time taken to insert needle was much less at 8 seconds (IQR 6 to 11) in Automated Epimatic Syringe group, in comparison to 35 seconds (IQR 28, 45) in conventional LOR syringe group, which was statistically significant ( $\mathrm{P}$ value $<0.001$ )

\begin{tabular}{|c|c|c|c|}
\hline \multirow[b]{2}{*}{ Parameter } & \multicolumn{2}{|c|}{ Group } & \multirow[b]{2}{*}{$\begin{array}{c}\text { Fisher's } \\
\text { Exact Text } \\
\text { P-Value }\end{array}$} \\
\hline & $\begin{array}{c}\text { Automated } \\
\text { Epimatic } \\
\text { Syringe }\end{array}$ & $\begin{array}{c}\text { Conventional } \\
\text { LOR Syringe }\end{array}$ & \\
\hline \multicolumn{4}{|c|}{ Ease of Identification } \\
\hline Clear & $17(85 \%)$ & $14(70 \%)$ & \multirow{2}{*}{0.450} \\
\hline Barely \& None & $3(15 \%)$ & $6(30 \%)$ & \\
\hline \multicolumn{4}{|c|}{ Ease of Catheter Insertion } \\
\hline No Resistance & $17(85 \%)$ & $13(65 \%)$ & \multirow[b]{2}{*}{0.273} \\
\hline $\begin{array}{c}\text { Mild Resistance } \\
\text { and not able to } \\
\text { Insert }\end{array}$ & $3(15 \%)$ & $7(35 \%)$ & \\
\hline $\begin{array}{c}\text { Table } 4 \\
\text { with }\end{array}$ & $\begin{array}{l}\text { ciation c } \\
\text { of Stud }\end{array}$ & $\begin{array}{l}\text { se of Identi) } \\
\text { pulation ( }\end{array}$ & $\begin{array}{l}\text { tion } \\
\text { D) }\end{array}$ \\
\hline
\end{tabular}

Among the automated Epimatic syringe cases, clear identification was done in 17 (85\%), barely identifiable and no identification was observed in $15 \%$ of the subjects. These proportions were $70 \%$ and $30 \%$ in the conventional LOR syringe group. The difference in the proportion between the two groups was statistically not significant using Fisher's exact test. $(\mathrm{P}$ value $=0.450)$.

Among the automated Epimatic syringe cases, needle was inserted with no resistance in $17(85 \%)$, mild and complete resistance was observed in remaining $15 \%$ of the subjects. In the conventional LOR group, these proportions were $65 \%$ and $35 \%$ respectively. The difference in the proportion between the two groups was statistically not significant using Fisher's exact test. $(\mathrm{P}$ value $=0.273)$.

\section{DISCUSSION}

The current study, which was conducted to compare the ease of epidural needle insertion with automated Epimatic syringe and conventional LOR syringe has demonstrated that the proportion of subjects with needle insertion in first attempt was much higher at $80 \%$ with Automated Epimatic syringe as compared to $55 \%$ in in conventional LOR syringe. About $5 \%$ of the subjects in conventional group required 4 attempts whereas none in the intervention groups required 4 attempts. In the study by Duniec L et al(3), no statistical difference was found between the conventional LOR and automatic syringe groups in number of needle insertion attempts, in contrast to current study.

The median amount of time taken to insert needle was also much less at 8 seconds in Automated Epimatic Syringe group, in comparison to 35 seconds in conventional LOR syringe group ( $\mathrm{P}$ value $<0.001$ ) in the current study. In study by Sawada A et al,(9) the time required to perform epidural anaesthesia was significantly shorter in the intervention group which has used Epidrum as compared to conventional method as in current study [28 s (10-76) vs. $90 \mathrm{~s}$ (34-185)].

Even though in higher proportion of subjects in automated Epimatic syringe group clear identification was done and no resistance was observed, when compared to conventional LOR group, these differences between the two groups were statistically not significant using Fisher's exact test ( $\mathrm{P}$ value $>0.05)$. Tielens $\mathrm{L} \mathrm{K}$ et al ${ }^{(10)}$ have also reported correct identification of epidural space by automatic syringe in paediatric patients. In a study by Duniec L et al,(3) the ease of epidural space identification, as assessed by an anaesthetist, was significantly better $(\mathrm{P}=0.011)$ in the automated group ( $87.5 \%$ vs. $52.4 \%)$, but there were no differences in the patient acceptance rate between the two techniques.

Few other studies by Saberski L R et al,(11) Dhansura T et al(12) (2015) have proved simple loss of resistance technique is safe and effective in resource-poor settings.

\section{Limitations}

Study sample is less, more numbers are needed for definitive results, and this is not a blinded study.

\section{CONCLUSION}

Automated Epimatic syringe being a newer hands-free technique taking less time to identify the space with less complications is an ideal technique for beginners. It is a safe alternative for conventional loss of resistance technique. Hence, it can be concluded that till more cost-effective technologies are made available, as recommended by some of the studies, conventional LOR method may be an appropriate and cost effective choice in resource-poor settings. But wherever the affordability is not a concern, the advanced technologies like automated Epimatic syringe should be used considering the quicker insertion time, less number of attempts and higher success rate. The gain in the anaesthetist's time may outweigh the cost of these advanced techniques.

\section{REFERENCES}

[1] Gerheuser F, Roth A. Epidural anesthesia. Der Anaesthesist 2007;56(5):499-523.

[2] Dawkins M. The identification of the epidural space. A critical analysis of the various methods employed. Anaesthesia 1963;18(1):66-77.

[3] Duniec L, Nowakowski P, Sieczko J, et al. Comparison of the techniques for the identification of the epidural space using the loss-of-resistance technique or an 
automated syringe - results of a randomized doubleblind study. Anaesthesiology Intensive Therapy 2016;48(4):228-33.

[4] Wantman A, Hancox N, Howell PR. Techniques for identifying the epidural space: a survey of practice amongst anaesthetists in the UK. Anaesthesia 2006;61(4):370-5.

[5] Singhal S, Bala M, Kaur K. Identification of epidural space using loss of resistance syringe, infusion drip and balloon technique: a comparative study. Saudi Journal of Anaesthesia 2014;8(Suppl 1):S41-5.

[6] Lund PC. The history of peridural anesthesia. International Anesthesiology Clinics 1964;2:471-5.

[7] Ikle A. Peridural anesthesia in labor. Der Anaesthesist 1953;2(1):29-33.

[8] Baraka A. Identification of the peridural space by a running infusion drip. British Journal of Anaesthesia 1972;44(1):122.
[9] Sawada A, Kii N, Yoshikawa Y, et al. Epidrum((R)): a new device to identify the epidural space with an epidural Tuohy needle. Journal of Anesthesia 2012;26(2):292-5.

[10] Tielens LK, Bruhn J, Vogt $M$, et al. The Episure Autodetect syringe, a loss-of-resistance technique for locating the epidural space, used in pediatric patients. Paediatric Anaesthesia 2013;23(8):747-50.

[11] Saberski LR, Kondamuri S, Osinubi OY. Identification of the epidural space: is loss of resistance to air a safe technique? A review of the complications related to the use of air. Regional Anesthesia 1997;22(1):3-15.

[12] Dhansura T, Shaikh T, Maadoo M, et al. Identification of the epidural space-loss of resistance to saline: An inexpensive modification. Indian Journal of Anaesthesia 2015;59(10):677-9. 